in vivo $35: 3603-3612(2021)$

doi:10.21873/invivo.12666

\title{
Epidermal Growth Factor Is Increased in Conjunctival Malignant Melanoma
}

\author{
VINODH KAKKASSERY ${ }^{1,2}$, CHRISTOPH WIRTZ ${ }^{1}$, MARC SCHARGUS ${ }^{1,3,4}$, \\ SALVATORE GRISANTI $^{2}$, AYSEGÜL TURA $^{2}$, MAHDY RANJBAR $^{2}$, H. BURKHARD DICK $^{1}$, \\ SABRINA REINEHR ${ }^{1 *}$ and STEPHANIE C. JOACHIM ${ }^{1 *}$ \\ ${ }^{1}$ Experimental Eye Research Institute, University Eye Hospital, Ruhr-University Bochum, Bochum, Germany; \\ ${ }^{2}$ Department of Ophthalmology, University of Lübeck, Lübeck, Germany; \\ ${ }^{3}$ Department of Ophthalmology, Heinrich-Heine-University, Düsseldorf, Germany; \\ ${ }^{4}$ Department of Ophthalmology, Asklepios Hospital Nord-Heidberg, Hamburg, Germany
}

\begin{abstract}
Background/Aim: Conjunctival malignant melanoma (CMM) is a rare, but very aggressive tumor with a high metastasis rate. Not much is known about the CMM metastasis mechanisms. So far, epidermal growth factor (EGF) and its receptor (EGF-R) as well as macrophages and matrix metalloproteinase 9 (MMP-9) have been reported to lead to metastasis by epithelial-mesenchymal-transition and tumor migration in different solid tumors. Therefore, we evaluated whether EGF and EGF-R, CD68 and MMP-9 are altered in CMM samples in comparison to conjunctival nevi and healthy conjunctiva. Patients and Methods: EGF, EGF$R$, the macrophage marker CD68 and MMP-9 expression were analyzed in human conjunctival melanoma (CMM, $n=16)$, human conjunctival nevi $(n=13)$ and disease-free human conjunctiva (controls, $n=14$ ) by immunohistology. Staining of each sample was evaluated using a standardized score ranging from negative (0) to triple positive (3). The groups were then compared by ANOVA, followed by Tukey's post-hoc test. Results: A statistically significant increase of EGF was seen in CMM samples in comparison to conjunctival nevi $(p=0.03)$. In contrast, no statistically significant differences in EGF-R expression were noted between the three groups. A statistically significant increase of CD68 was only seen in conjunctival nevi compared to
\end{abstract}

This article is freely accessible online.

*These Authors contributed equally to this work.

Correspondence to: Vinodh Kakkassery, MD, Department of Ophthalmology, UKSH, University of Lübeck, Ratzeburger Allee 160, 23538 Lübeck, Germany. Tel: +49 45150043911, Fax: +49 45150043914, e-mail: vinodh.kakkassery@gmail.com

Key Words: EGF, EGF-receptor, MMP-9, macrophage, conjunctival malignant melanoma. controls $(p=0.04)$. MMP-9 expression was similar in all groups. Conclusion: In CMM, the study data demonstrated an up-regulation of EGF in comparison to conjunctival nevi. Hence, EGF might promote proliferation of CMM cells and induce the epithelial-mesenchymal transition. Therefore, our data suggest that an interplay between EGF and CMM might have a critical role in the developing CMM tumors and metastasis.

Conjunctival malignant melanoma (CMM), with an estimated annual incidence of 0.04 per 100.000 people, is a rare but extremely malignant tumor (1-3). The 10 year mortality rate of $30 \%$ demonstrates its high malignancy (2). Progress in local tumor control and reduction in the rate of local recurrence in the last 20 to 30 years has not had any positive effect on CMM metastasis rate (4-10).

Several clinical and histopathological prognostic factors for CMM metastasis have been evaluated so far. Tumor thickness, ulcerative tumor invasion in the sclera and feeder vessels as well as lymph vascular invasion, microsatellites, mitotic figures and epithelioid cell types are clinical and histopathological risk factors for metastasis (5, 7-9, 11-15). Also, dermatoscopy may further clinically discriminate between nevi and CMM (16). Recently, Esmaeli et al. demonstrated that a higher TNM classification grading of conjunctival melanoma (following the $8^{\text {th }}$ edition of the American Joint Committee on Cancer) exhibited a higher risk for metastasis. Also, this group noted that greater tumor thickness, ulceration or positive sentinel lymph node correlated with metastasis (17). Furthermore, Kenawy et al. detected a genetic deletion on chromosome 10 in conjunctival melanoma samples, which was correlated with metastasis, lymphatic invasion, increased tumor thickness and BRAF mutation (18). Larsen et al. discovered a higher metastasis risk for extrabulbar CMM as well as for CMM undergoing an incisional biopsy or an excisional biopsy 
Table I. Summary of biodata of CMM samples.

\begin{tabular}{|c|c|c|c|c|c|c|c|c|}
\hline Sample & Eye & $\begin{array}{l}\text { Age at } \\
\text { excision }\end{array}$ & Gender & $\begin{array}{c}\text { TNM } \\
\text { classification }\end{array}$ & $\begin{array}{l}\text { Adjuvant } \\
\text { therapy }\end{array}$ & Metastasis & $\begin{array}{l}\text { Location of } \\
\text { metastasis }\end{array}$ & Recurrence \\
\hline 1 & Right & 57 & Male & pT(is)NOM0 & Strontium-90 & No & - & No \\
\hline 2 & Right & 44 & Male & pT(is)NOM0 & Ruthenium-106 & No & - & No \\
\hline 3 & Left & 77 & Male & pT(is)N0M0 & Strontium-90 & No & - & Yes \\
\hline 4 & Left & 65 & Male & pT(is)NOM0 & External beam & No & - & Yes \\
\hline 5 & Right & 67 & Male & pT(is)NOM0 & Strontium-90 & No & - & No \\
\hline 6 & Right & 58 & Male & pT(is)NOM0 & Strontium-90 & No & - & No \\
\hline 7 & Left & 55 & Male & pT(is)NOM0 & Strontium-90 & No & - & Yes \\
\hline 8 & Left & 28 & Male & pT(is)NOM0 & Ruthenium-106 & No & - & No \\
\hline 9 & Left & 76 & Male & $\mathrm{pT}$ (is)N1M1 & Strontium-90 & Yes & $\begin{array}{l}\text { Cervical lymph nodes, } \\
\text { pulmonal, pleural and } \\
\text { hepatical distal metastasis }\end{array}$ & Yes \\
\hline 10 & Right & 31 & Female & pT(is)NOM0 & Strontium-90 & No & - & Yes \\
\hline 11 & Right & 67 & Female & pT(is)NOM0 & Strontium-90 & No & - & No \\
\hline 12 & Right & 81 & Female & pT(is)NOM0 & External beam & No & - & No \\
\hline 13 & Right & 65 & Male & pT(is)NOM0 & External beam & No & - & No \\
\hline 14 & Right & 73 & Female & pT(is)NOM0 & $\begin{array}{l}\text { Mitomycin C } \\
\text { eye drops, } \\
\text { cryocoagulation }\end{array}$ & No & - & No \\
\hline 15 & Right & 65 & Male & pT(is)N0M0 & External beam & No & - & No \\
\hline 16 & Left & 87 & Female & $\mathrm{pT}$ (is)N1M0 & $\begin{array}{l}\text { Mitomycin C } \\
\text { eye drops, } \\
\text { cryocoagulation }\end{array}$ & Yes & $\begin{array}{l}\text { Lymph nodes } \\
\text { glandula parotis }\end{array}$ & Yes \\
\hline
\end{tabular}

without adjuvant radiotherapy (19). Therefore, many clinical and histopathological risk factors for CMM metastasis are known and can be linked with epithelial-mesenchymaltransition and tumor cell migration, but not much is known regarding molecular mechanisms of CMM metastasis. So far, upregulation of mucin 4 protein (MUC 4) in CMM has been linked with CMM migration (20). Additionally, investigations in CMM noted a UV light-induced mutational signature (21). Also, Heindl and colleagues observed the development of lymphatic vessels in primary CMM and especially in CMM with metastasis $(22,23)$.

Hanahan and Weinberg have postulated that local tumor invasion capacity as well as epithelial-mesenchymaltransition are critical steps for migration and metastasis in solid tumors $(24,25)$. In different solid tumors, especially in cutaneous melanoma, epidermal growth factor (EGF) and EGF-receptor (EGF-R), macrophages and matrix metalloproteinase 9 (MMP-9) trigger metastasis, through e.g., local tumor migration and epithelial-mesenchymal-transition. Li et al. noted activation of metastasis inducing pathways by EGF, EGF-R and MMP-9 in two cutaneous cell lines (26). Furthermore, Treskova et al. investigated EGF plasma levels and correlated higher levels with lymph node metastasis in cutaneous melanoma (27). Also, Bracher et al. showed a significant upregulation of EGF in human primary cutaneous melanoma tissue of metastatic patients (28). Foks et al. revealed a correlation between macrophages and more advanced cutaneous melanoma including higher microvessel density and poor prognosis (29). In a study by Licarete et al., the effect of tumor-associated macrophages was suppressed in a cutaneous melanoma cell line and hereby reduced the activity of these cells (30). Until now, upregulation of EGF, EGF-R, macrophages and MMP-9 has not been investigated in CMM. Therefore, expression patterns and localization of these factors in CMM might provide new information to facilitate our understanding of the pathogenesis of CMM metastasis.

The objective of this study was to analyze whether EGF, EGF-receptor, CD68 (a macrophage marker) and MMP-9 are up-regulated in human CMM samples in comparison to conjunctival nevi and healthy conjunctiva. These data might elucidate tumor cell migration to vessels for metastasis and might therefore indicate how metastasis develops in CMM.

\section{Patients and methods}

Sample collection. For sample collection, approval was obtained from the Ruhr-University Bochum ethics committee (register no 4850-13; Bochum, Germany); the study was conducted following the guidelines of the Helsinki declaration.

Analysis was conducted on CMM ( $n=16$ for EGF and EGF-R; $n=14$ for CD68 and MMP-9; Table I), conjunctival nevi ( $n=13)$, and healthy conjunctival epithelial samples without any pigmentation (controls, $n=14$ ). CMM and conjunctival nevus tissue was obtained by excision for diagnostic reasons. Healthy conjunctival tissue was 
Kakkassery et al: Epidermal Growth Factor in Conjunctival Melanoma

Table II. Primary and secondary antibodies used for immunohistology.

\begin{tabular}{|c|c|c|c|c|c|c|}
\hline Primary antibody & Company & Dilution factor & Secondary antibody & Company & Dilution factor & Reference \\
\hline EGF goat anti-human & Santa Cruz & $1: 100$ & Donkey anti-goat Alexa 488 & Invitrogen & $1: 500$ & $(60)$ \\
\hline EGF-R rabbit anti-human & Santa Cruz & $1: 100$ & Donkey anti-rabbit Alexa 555 & Invitrogen & $1: 700$ & (31) \\
\hline MMP-9 rabbit anti-human & Millipore & $1: 400$ & & & & (33) \\
\hline CD68 mouse anti-human & DAKO & $1: 100$ & Goat anti-mouse Alexa 488 & Invitrogen & $1: 500$ & $(32)$ \\
\hline
\end{tabular}

obtained from patients undergoing strabismus surgery. For all CMM samples, clinical biodata was collected (Table I).

Immunohistology. Immunohistology was performed as previously described (20). Conjunctival biopsies were fixed in $4 \%(\mathrm{w} / \mathrm{v})$ formalin, dehydrated in an ethanol series and then embedded in paraffin. Serial sections ( $4 \mu \mathrm{m}$ thick) were de-paraffinized and rehydrated. High-temperature antigen-retrieval was performed by applying $0.05 \%$ sodium-citrate buffer $(\mathrm{pH} 6)$ for $20 \mathrm{~min}$. Staining was performed for all samples to enable association of immune histochemical staining with structures within the samples.

Sections were processed for immunofluorescence microscopy using antibodies against EGF (31), EGF-R (31), CD68 (32) and MMP-9 (33) (Table II). Sections were blocked for 60 minutes at room temperature. After two washing steps with PBS for 5 minutes, the primary antibody was incubated overnight. After four further wash out steps with PBS, appropriate secondary antibodies were applied for 60 minutes. DAPI co-staining was applied to visualize cell nuclei. Negative controls were performed by using only secondary antibodies.

Digital images were taken from two sections per sample with six images per section using an Axio Image M1 Microscope (Zeiss, Oberkochen, Germany). Immunohistological analysis was performed following a previously established score for CMM, analog to the Remmele score for breast cancer $(34,35)$. Each sample was divided in sectors of similar area and separately scored following an established scoring system ranging from 0 to $3(0=$ no signal/not a single cell was stained; $1=$ minor signal/cells were stained sporadically; $2=$ moderate to high signal/couple of cells were stained within a cell layer; $3=$ high signal/couple of cells were stained within different cell layers). The scoring system was used for EGF, EGF-R, CD68 and MMP-9. Data was used for further statistical analysis.

Statistical analysis. Data are presented as mean \pm SEM. The three groups were compared by ANOVA followed by Tukey's post-hoc test using Statistica software (V13.0, Statsoft, Dell, Tulsa, OK, USA). $p$-Values below 0.05 were considered statistically significant with $* p<0.05, * * p<0.01$ and $* * * p<0.001$.

\section{Results}

Bio data. For EGF analysis, $16 \mathrm{CMM}$ samples (10 primary tumors and 6 recurrent tumors, two of which developed CMM metastasis) as well as 13 conjunctival nevi samples and 14 healthy conjunctival samples (controls) were used. The average age of CMM patients was $62 \pm 17$ years with 5 females and 11 males. The conjunctival nevi patients had an average age of $41 \pm 17$ years and this group had 8 female and 5 male patients. The healthy conjunctiva group consisted of 14 patients with an average age of $14 \pm 22$ years; 7 were females and 7 males. Detailed biodata (gender, age at diagnosis, eye, TNM level, recurrence after, excision metastasis after excision, therapy) for all $16 \mathrm{CMM}$ samples are displayed in Table I. For CD68 and MMP-9 analysis, only CMM sample numbers 1 to 14 were used, due to limited tissue.

EGF upregulation around epithelial cell membranes in $C M M$. EGF staining was localized at the epithelial cell membranes of CMM, conjunctival nevi, and controls (Figure 1A). Staining investigations and scoring demonstrated increased EGF expression in CMM (mean score of $0.56 \pm 0.12)$ in comparison to conjunctival nevi $(0.18 \pm 0.05$, $p=0.03$ ). No statistical significance was seen between CMM and controls (mean score $0.23 \pm 0.09, p=0.055$ ) and between conjunctival nevi and controls ( $p=0.94$; Figure 1B).

Sub-analysis of two CMM with history of metastasis even showed a mean EGF score of 1.12. These samples displayed an even higher score than all other CMM samples. Statistical analysis was not done between CMM with and without metastasis history due to the low number of CMM with metastasis history.

Sub-analysis of two CMM recurrences showed a mean EGF score of 0.39. These samples displayed a lower score then all other CMM samples. Statistical analysis was not done between CMM with recurrence history and primary CMM due to the low number of CMM recurrences.

EGF-R staging intensity and localization was comparable in all samples. EGF-R staining was localized at the epithelial cell membranes of CMM, conjunctival nevi, and controls (Figure 1A). Staining investigations demonstrated no statistical difference of EGF-R score between CMM (mean score of $0.99 \pm 0.15$ ) and conjunctival nevi (mean score of $1.08 \pm 0.12, p=0.92$ ), as well as between CMM and controls (mean score of $0.75 \pm 0.18, p=0.53$ ). No statistically 


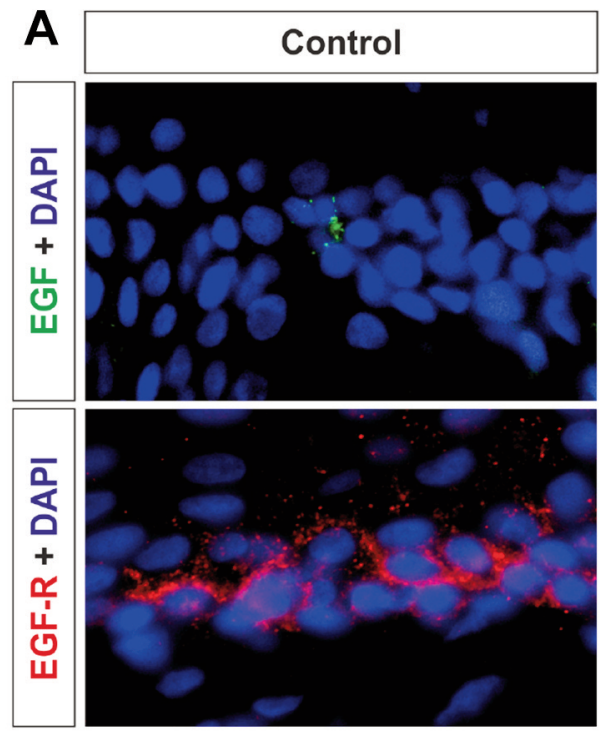

B

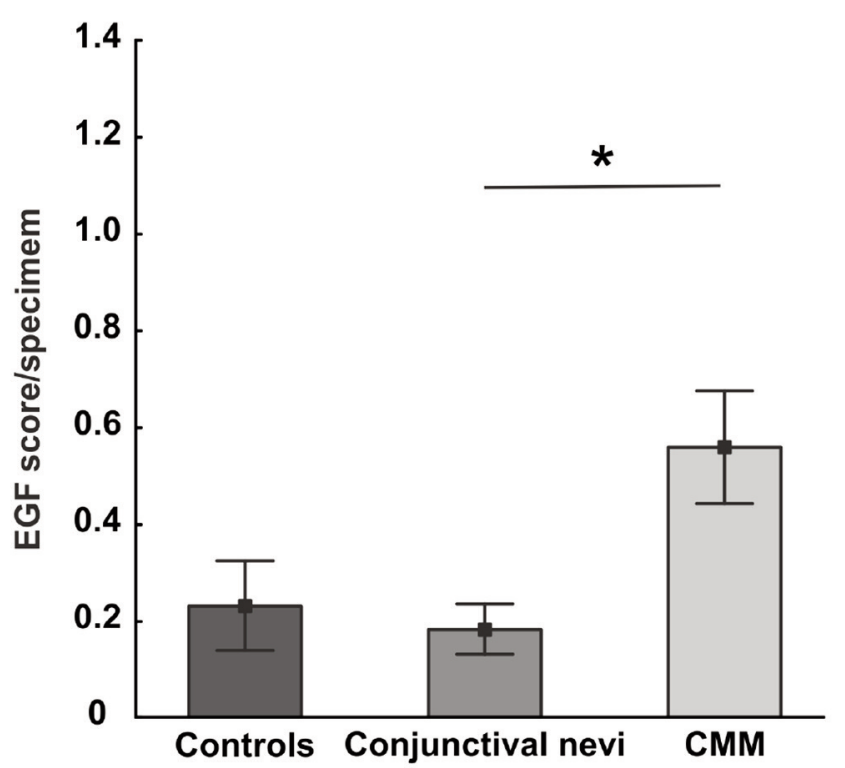

C

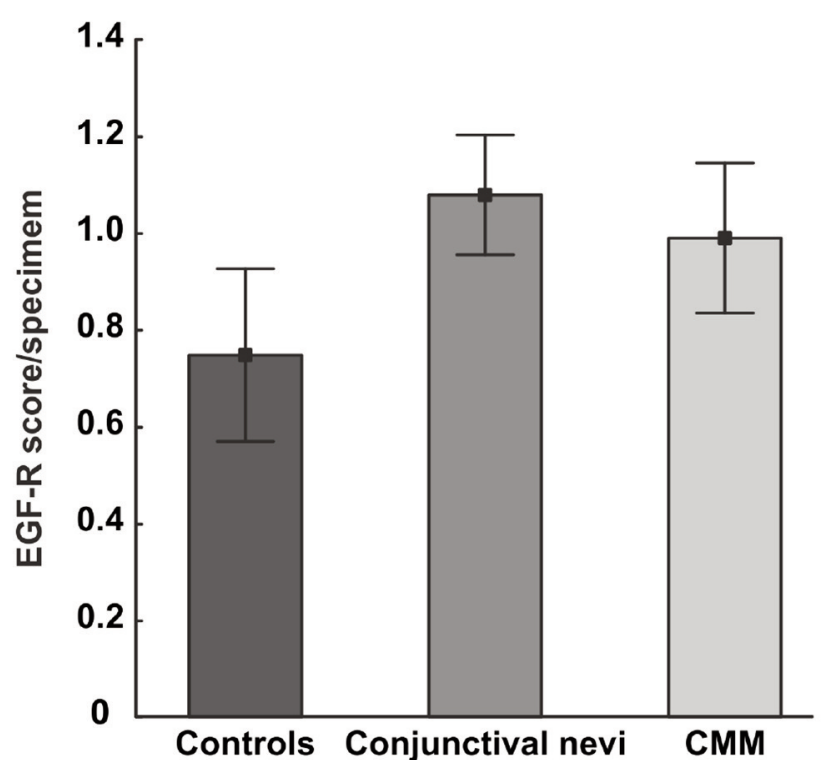

Figure 1. Immunofluorescence analysis of EGF and EGF-R-expression. A) Immunofluorescence staining of EGF (green) and EGF-R (red) was performed on disease-free conjunctiva (control, $n=14)$, conjunctival nevi $(n=13)$, and conjunctival melanoma $(C M M, n=16)$. Cell nuclei were visualized with DAPI (blue). B) Significantly increased EGF expression was noted in melanoma compared to nevi ( $p=0.03)$, but not compared to controls ( $p=0.055)$. C) In regard to EGF-R, comparable scores were observed in the three investigated groups. Values are mean \pm SEM. Scale bar: $20 \mu m$. * $p<0.05$.

significant difference was noted between conjunctival nevi and control tissue ( $p=0.33$, Figure 1C).

Sub-analysis of two CMM with metastasis history even showed a mean value EGF-R score of 1.1 and did not show a striking difference to other CMM samples. Sub-analysis of two CMM recurrences revealed a mean EGF-R score of 0.89 . These samples displayed a lower score then all other CMM samples. Statistical analysis was not done between
CMM with recurrence history and primary CMM due to the low number of CMM recurrences. CMM recurrence samples had a mean EGF, EGF-R, CD68 and MMP-9 score of 0.39, $0.89,0.55$ and 1.0 , respectively.

CD $68^{+}$macrophage expression did not demonstrate any differences between CMM and conjunctival nevi. $\mathrm{CD}^{+} 8^{+}$ macrophage staining was localized at the epithelial cell 

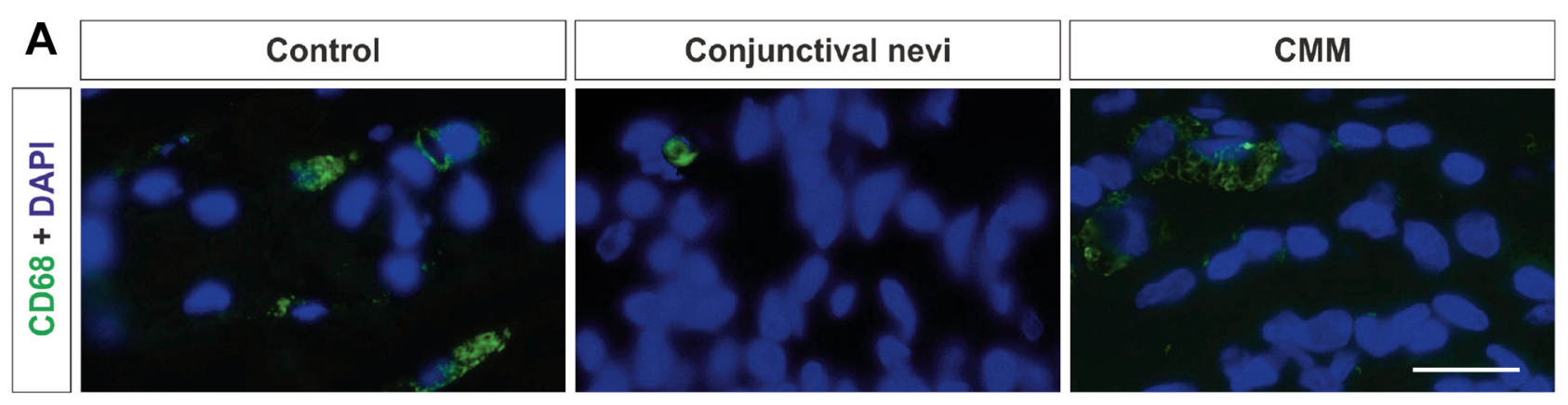

B

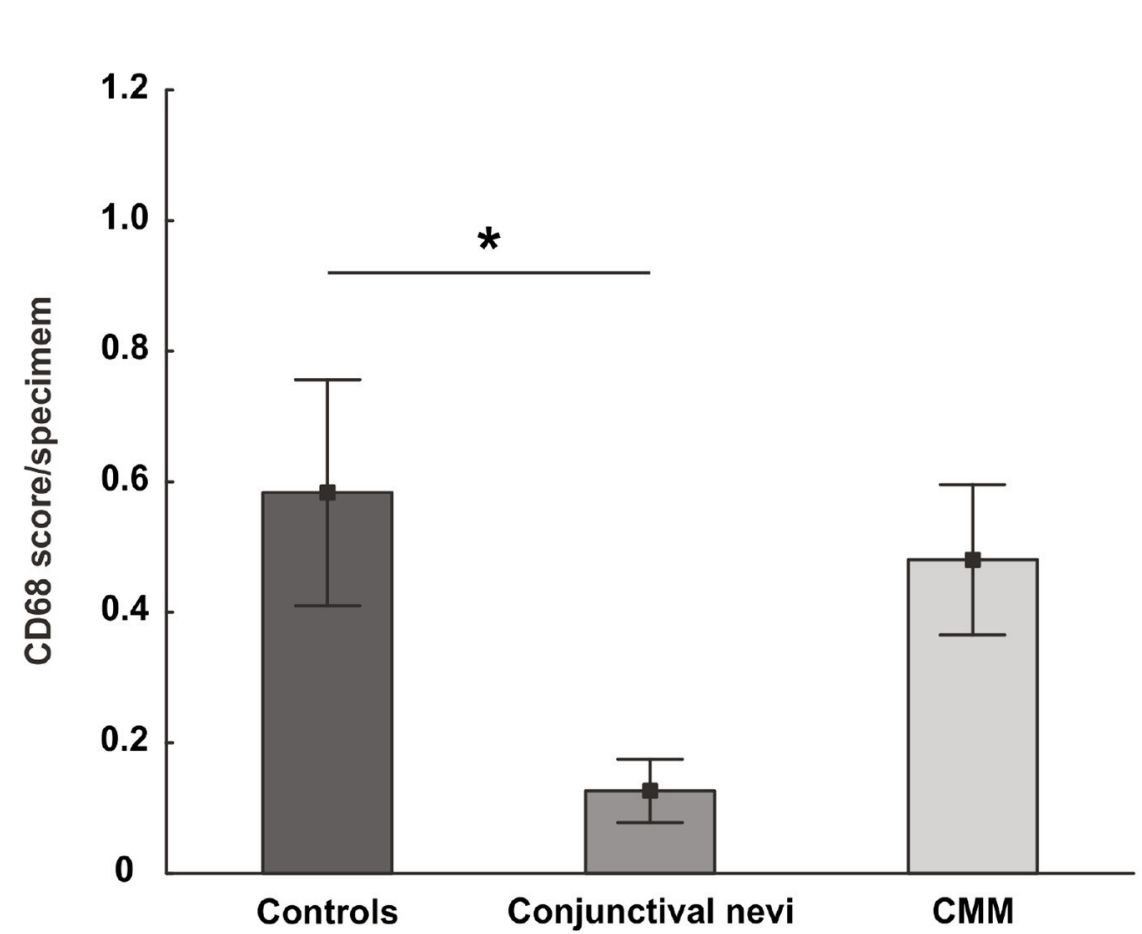

Figure 2. Immunofluorescence analysis of macrophage incidence. A) Immunofluorescence staining of CD68 (green), a highly glycosylated lysosomal membrane protein found in macrophages, was performed on healthy conjunctiva (control, $n=14)$, conjunctival nevi ( $n=13)$, and conjunctival melanoma (CMM, $n=14)$. Cell nuclei were stained with DAPI (blue). B) There was no statistical difference for CD6 $8^{+}$cell scores in CMM compared to conjunctival nevi. Healthy conjunctiva presented more macrophages in comparison to conjunctival nevi ( $p=0.04)$. Values are mean \pm SEM. Scale bar: $20 \mu m . * p<0.05$.

membranes of CMM, conjunctival nevi, as was well as controls (Figure 2A). Staining investigations demonstrated no statistical difference of $\mathrm{CD}^{+} 8^{+}$cell score between CMM (mean score of $0.48 \pm 0.11$ ) and conjunctival nevi (mean score of $0.13 \pm 0.05$, $p=0.12$ ), as well as between CMM and controls (mean score of $0.58 \pm 0.17, p=0.83$ ). A statistically significant difference was only seen between conjunctival nevi and control tissue $(p=0.04$, Figure 2B). Sub-analysis of two CMM with metastasis history even showed a mean CD68 score of 0.49 and did not display a striking difference to other CMM samples.

Sub-analysis of two CMM recurrences showed a mean CD68 score of 0.55 . These samples displayed a higher score than all other CMM samples. Statistical analysis was not carried out between CMM with recurrence history and primary CMM due to the low number of CMM recurrences.

MMP-9 intensity and localization were similar for CMM, nevi, and controls. MMP-9 staining was localized at the epithelial cell membranes of CMM, conjunctival nevi, and controls (Figure 3A). MMP-9 staining investigations demonstrated no statistical difference between CMM (mean score of $0.97 \pm 0.46$ ) and conjunctival nevi (mean score of $1.07 \pm 0.52, p=0.85$ ), as well as between CMM and controls (mean score of $0.89 \pm 0.43, p=0.91$; Figure $3 \mathrm{~B}$ ). Also, no 

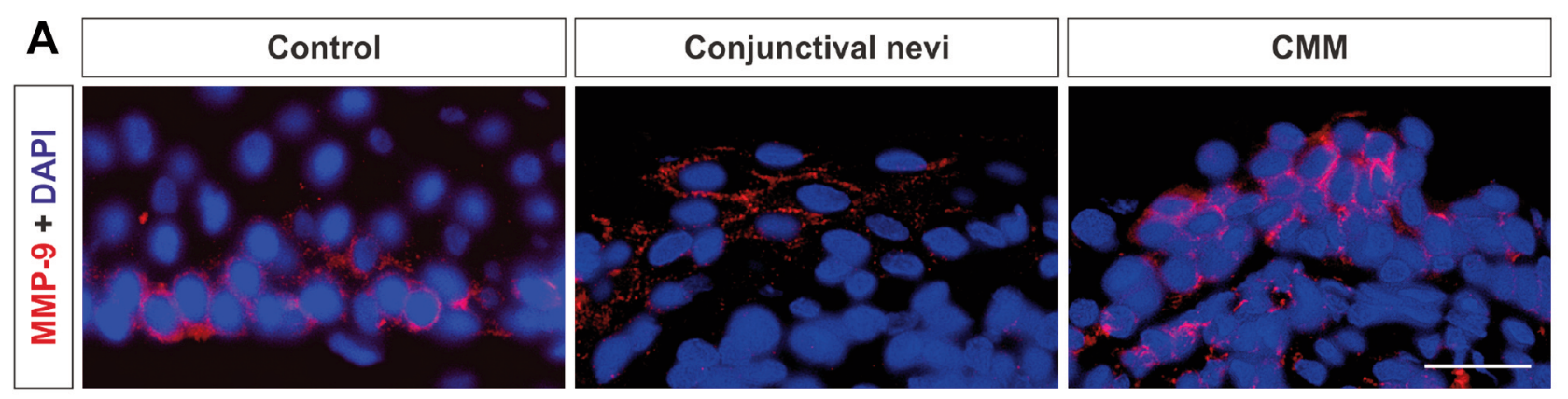

B

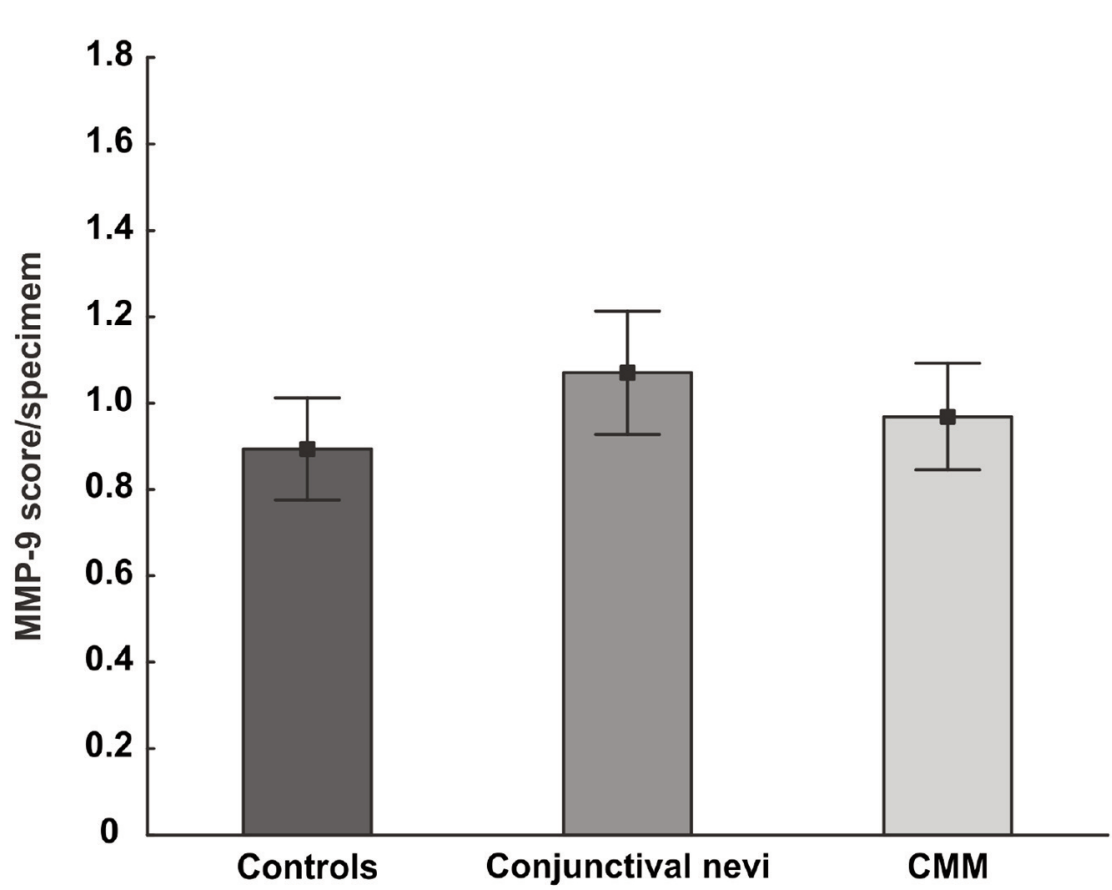

Figure 3. Evaluation of MMP-9 expression. A) Immunofluorescence staining of MMP-9 (red) was performed on healthy conjunctiva (control, $n=14)$, conjunctival nevi $(n=13)$ and conjunctival melanoma $(C M M, n=14)$. Cell nuclei were visualized with DAPI (blue). B) No significant differences

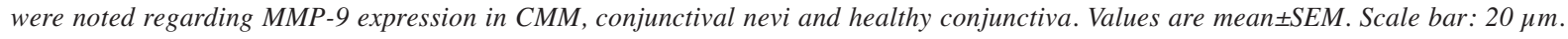

statistically significant differences were noted between conjunctival nevi and controls $(p=0.61)$. Sub-analysis of two CMM with metastasis history even showed a mean MMP-9 score of 1.07 and did not reveal a difference to other CMM samples. Sub-analysis of two CMM recurrences presented a mean MMP-9 score of 1.00. These samples displayed the highest score of all CMM samples. Statistical analysis was not done between CMM with recurrence history and primary $\mathrm{CMM}$, again due to the low number of CMM recurrences.

\section{Discussion}

In our study, EGF, EGF-R, CD68 and MMP-9 were located on the epithelial cell membrane of CMM nevi and controls.
We detected a statistically significantly increased EGF score in CMM samples compared to conjunctival nevi. In contrast, values for EGF-R were comparable in all groups. No significant differences were seen regarding $\mathrm{CD}^{+} 8^{+}$ macrophages in CMM samples compared to conjunctival nevi and controls. Also, a similar expression of MMP-9 was noted in all these tissues.

So far, there have not been any investigations regarding EGF and its receptor in CMM. Meng et al. observed that EGF is significantly upregulated in human breast cancer tissue and associated with metastatic progression and enhanced cancer cell migration and invasion (36). In addition, $\mathrm{Xu}$ et al. discovered that epithelial-mesenchymal-transition is EGFdependent in hepatocellular carcinoma cells and mouse 
xenographs (37). In another study, Cheng et al. noted that ovarian tumor cell lines downregulate E-cadherin after EGF incubation, including a higher motility and invasiveness of the tumor cells. These effects could be inhibited by siRNA or inhibitors for EGF-R (38). Ma and Niederkorn injected different uveal cell lines into a nude mouse model and observed higher grades of metastasis to the liver depending on the grade of EGF-R in each cell line (39). Furthermore, several research groups have demonstrated that BRAF inhibitor resistance is linked with the upregulation of EGF and EGF-R in cutaneous melanoma cells and that this inhibitory effect is associated with EGF and EGF-R downregulation (4046). Therefore, an inhibition of BRAF is probably valuable, when EGF-EGF-R activity is also reduced in tumors, e.g., in colon carcinoma or CMM. All these findings are in accordance with the EGF upregulation detected in our study. Therefore, EGF upregulation might play a role in CMM malignancy. Nevertheless, no increase in EGF-R expression was seen in our CMM analysis. Recognizing the upregulation of EGF in our study, an upregulation of EGF-R was expected in CMM but was not seen in our samples.

So far, different research groups demonstrated the important role of macrophages in cutaneous melanoma metastasis (47-49). Storr et al. observed a correlation between higher macrophage levels and increased ulceration rates, tumor thickness, mitosis rates, as well as infiltration rates of lymph and blood vessels in cutaneous melanoma (49). Also, Jensen et al. reported a slightly lower survival rate in cases with a higher number of macrophages in the primary tumor tissue in this skin malignancy but did not differentiate between tissue with and without metastasis history (47). In addition, EGF expression is induced by macrophages in different solid tumors and may explain the EGF upregulation in CMM (50-53). Furthermore, in breast cancer, cell migration and invasion are triggered by macrophages and EFG (54). Our data are not in line with the previous results from cutaneous melanoma; our results showed a higher, but statistically not significant, level of macrophages in CMM in comparison to conjunctival nevi. These results are therefore not a hint for tumor associated macrophages as a mechanism for metastasis. Furthermore, the highest number of macrophages was seen in controls, which might be due to the younger patients in this group.

Kim et al. previously investigated MMP-9 levels in CMM in comparison to conjunctival nevi without seeing any differences. A sub-analysis of CMM samples with a clinical diameter $>1.5 \mathrm{~mm}$ has demonstrated a higher level of MMP9. The authors concluded that MMP-9 might play a role in advanced CMM (55). In addition, Candrea et al. analyzed cutaneous malignant melanomas thicker than $2 \mathrm{~mm}$ and noted a higher amount of active and inactive MMP-9 in these samples compared to benign nevi. The same study revealed a correlation between expression of inactive MMP-9 and lymphatic metastasis (56). Van den Oord et al. also detected an upregulation of MMP-9 in cutaneous malignant melanoma. Surprisingly, thinner lesions had higher amounts of MMP-9 than thicker lesions (57). An accumulation of macrophages in lung metastasis tissue of gastric cancer patients was also noted in a current study (58). In addition, in a mouse model for this disease, macrophages secreted MMP-9 and induced an epithelial-mesenchymal transition (58). Increased nasopharyngeal cancer cell migration was described after MMP-9 downregulation (59). In contrast to these important effects of MMP-9 in solid tumors, we did not detect an MMP-9 upregulation in CMM samples.

The study presented here has some limitations. The patient's history has been collected to the best of our knowledge. However, previous studies and clinical experience has shown that especially in cases of metastasis, a loss of patients has been seen and follow-up information is limited. Further, due to the rarity of the disease, there are limited cases in this study.

Taken together, we previously noted a possible function of MUC4 in CMM metastasis by epithelial-mesenchymal transition and tumor migration (20). Our new data revealed an upregulation of EGF in CMM. EGF may promote proliferation of tumor cells and induce an epithelialmesenchymal transition. Therefore, EGF might play an important role in converting benign conjunctival lesions into CMM and for developing metastasis.

\section{Conflicts of Interest}

The Authors declare no conflicts of interest.

\section{Authors' Contributions}

Conceptualization: V.K.; Methodology: S.R., V.K., S.C.J.; Software: S.R., S.C.J.; Validation: C.W., M.S, S.G., M.R., A.T., H.B.D.; Formal Analysis: V.K., S.R., S.C.J.; Investigation: V.K., S.R., S.C.J, C.W., M.S,; Resources: H.B.D, S.C.J.; Data Curation: V.K., S.R., S.C.J; Writing - Original Draft Preparation: V.K.; Writing - Review \& Editing: V.K., S.R., S.C.J., C.W., M.S, S.G., M.R., A.T., H.B.D.; Visualization: V.K., S.R., S.C.J; Supervision: V.K., S.C.J.; Project Administration: V.K, S.C.J.; Funding Acquisition: V.K., S.C.J.; S.G..

\section{Acknowledgements}

We thank Ann-Christin Nick and Sandra Kühn for their excellent technical support.

\section{References}

1 Wilson MW, Hungerford JL, George SM and Madreperla SA: Topical mitomycin $\mathrm{C}$ for the treatment of conjunctival and corneal epithelial dysplasia and neoplasia. Am J Ophthalmol 124(3): 303-311, 1997. PMID: 9439356. DOI: 10.1016/s00029394(14)70822-0 
2 Lommatzsch PK and Werschnik C: [Malignant conjunctival melanoma. Clinical review with recommendations for diagnosis, therapy and follow-up]. Klin Monbl Augenheilkd 219(10): 710-721, 2002. PMID: 12447715. DOI: $10.1055 / \mathrm{s}-$ 2002-35693

3 Rossi E, Schinzari G, Maiorano BA, Pagliara MM, Di Stefani A, Bria E, Peris K, Blasi MA and Tortora G: Conjunctival melanoma: Genetic and epigenetic insights of a distinct type of melanoma. Int J Mol Sci 20(21): 5447, 2019. PMID: 31683701. DOI: $10.3390 / \mathrm{ijms} 20215447$

4 Norregaard JC, Gerner N, Jensen OA and Prause JU: Malignant melanoma of the conjunctiva: occurrence and survival following surgery and radiotherapy in a Danish population. Graefes Arch Clin Exp Ophthalmol 234(9): 569-572, 1996. PMID: 8880155. DOI: $10.1007 / \mathrm{BF} 00448801$

5 Shields CL, Shields JA, Gündüz K, Cater J, Mercado GV, Gross $\mathrm{N}$ and Lally B: Conjunctival melanoma: risk factors for recurrence, exenteration, metastasis, and death in 150 consecutive patients. Arch Ophthalmol 118(11): 1497-1507, 2000. PMID: 11074806. DOI: 10.1001/archopht.118.11.1497

6 Werschnik C and Lommatzsch PK: Long-term follow-up of patients with conjunctival melanoma. Am J Clin Oncol 25(3): 248-255, 2002. PMID: 12040282. DOI: 10.1097/00000421200206000-00009

7 Albreiki DH, Gilberg SM and Farmer JP: Conjunctival malignant melanoma: A rare variant and review of important diagnostic and therapeutic considerations. Saudi J Ophthalmol 26(2): 151-156, 2012. PMID: 23960986. DOI: 10.1016/j.sjopt. 2012.02.006

8 Kimura K, Usui Y and Goto H: [Clinical findings and prognosis of 11 cases of conjunctival malignant melanoma]. Nippon Ganka Gakkai Zasshi 116(5): 503-509, 2012. PMID: 22690541.

9 Costea CF, Anghel K, Dimitriu G, Dumitrescu GF, Faiyad Z, Dumitrescu AM and Sava A: Anatomoclinical aspects of conjunctival malignant metastatic melanoma. Rom J Morphol Embryol 55(3): 933-937, 2014. PMID: 25329123.

10 Miller CV, Cook IS, Jayaramachandran R and Tyers AG: Spontaneous regression of a conjunctival malignant melanoma. Orbit 33(2): 139-141, 2014. PMID: 24295209. DOI: 10.3109/ 01676830.2013 .851708

11 Anastassiou G, Heiligenhaus A, Bechrakis N, Bader E, Bornfeld $\mathrm{N}$ and Steuhl KP: Prognostic value of clinical and histopathological parameters in conjunctival melanomas: a retrospective study. Br J Ophthalmol 86(2): 163-167, 2002. PMID: 11815341. DOI: $10.1136 /$ bjo.86.2.163

12 Fuchs U, Kivelä T, Liesto K and Tarkkanen A: Prognosis of conjunctival melanomas in relation to histopathological features. Br J Cancer 59(2): 261-267, 1989. PMID: 2649132. DOI: 10.1038/bjc. 1989.55

13 Missotten GS, Keijser S, De Keizer RJ and De Wolff-Rouendaal D: Conjunctival melanoma in the Netherlands: a nationwide study. Invest Ophthalmol Vis Sci 46(1): 75-82, 2005. PMID: 15623757. DOI: 10.1167 /iovs.04-0344

14 Tuomaala S, Eskelin S, Tarkkanen A and Kivelä T: Populationbased assessment of clinical characteristics predicting outcome of conjunctival melanoma in whites. Invest Ophthalmol Vis Sci 43(11): 3399-3408, 2002. PMID: 12407149.

15 De Potter P, Shields CL, Shields JA and Menduke H: Clinical predictive factors for development of recurrence and metastasis in conjunctival melanoma: a review of 68 cases. $\mathrm{Br} \mathrm{J}$
Ophthalmol 77(10): 624-630, 1993. PMID: 8218029. DOI: 10.1136/bjo.77.10.624

16 DEbicka-Kumela M, Romanowska-Dixon B, Karska-Basta I, Kowal $\mathrm{J}$ and Markiewicz A: The evaluation of the malignant characteristics of conjunctival lesions based on the dermatoscopic algorithm. Anticancer Res 41(2): 895-903, 2021. PMID: 33517295. DOI: 10.21873/anticanres.14842

17 Esmaeli B, Rubin ML, Xu S, Goepfert RP, Curry JL, Prieto VG, Ning J and Tetzlaff MT: Greater tumor thickness, ulceration, and positive sentinel lymph node are associated with worse prognosis in patients with conjunctival melanoma: Implications for future AJCC classifications. Am J Surg Pathol 43(12): 1701-1710, 2019. PMID: 31425167. DOI: 10.1097/PAS.0000000000001344

18 Kenawy N, Kalirai H, Sacco JJ, Lake SL, Heegaard S, Larsen AC, Finger PT, Milman T, Chin K, Mosci C, Lanza F, Moulin A, Schmitt CA, Caujolle JP, Maschi C, Marinkovic M, Taktak AF, Heimann H, Damato BE and Coupland SE: Conjunctival melanoma copy number alterations and correlation with mutation status, tumor features, and clinical outcome. Pigment Cell Melanoma Res 32(4): 564-575, 2019. PMID: 30672666. DOI: $10.1111 / \mathrm{pcmr} .12767$

19 Larsen AC, Dahmcke CM, Dahl C, Siersma VD, Toft PB, Coupland SE, Prause JU, Guldberg P and Heegaard S: A retrospective review of conjunctival melanoma presentation, treatment, and outcome and an investigation of features associated with BRAF mutations. JAMA Ophthalmol 133(11): 1295-1303, 2015. PMID: 26425792. DOI: 10.1001/ jamaophthalmol.2015.3200

20 Kakkassery V, Winterhalter S, Nick AC, Joachim SC, Joussen $\mathrm{AM}$ and Kociok N: Vascular-associated Muc4/Vwf colocalization in human conjunctival malignant melanoma specimens-tumor metastasis by migration? Curr Eye Res 42(10): 1382-1388, 2017. PMID: 28622066. DOI: 10.1080/ 02713683.2017 .1324630

21 Cisarova K, Folcher M, El Zaoui I, Pescini-Gobert R, Peter VG, Royer-Bertrand B, Zografos L, Schalenbourg A, Nicolas M, Rimoldi D, Leyvraz S, Riggi N, Moulin AP and Rivolta C: Genomic and transcriptomic landscape of conjunctival melanoma. PLoS Genet 16(12): e1009201, 2020. PMID: 33383577. DOI: 10.1371/journal.pgen.1009201

22 Heindl LM, Hofmann-Rummelt C, Adler W, Bosch JJ, Holbach LM, Naumann GO, Kruse FE and Cursiefen C: Tumorassociated lymphangiogenesis in the development of conjunctival melanoma. Invest Ophthalmol Vis Sci 52(10): 7074-7083, 2011. PMID: 21849428. DOI: 10.1167/iovs.11-7902

23 Heindl LM, Hofmann-Rummelt C, Adler W, Bosch JJ, Holbach LM, Naumann GO, Kruse FE and Cursiefen C: Prognostic significance of tumor-associated lymphangiogenesis in malignant melanomas of the conjunctiva. Ophthalmology 118(12): 2351-2360, 2011. PMID: 21835473. DOI: 10.1016/ j.ophtha.2011.05.025

24 Hanahan D and Weinberg RA: The hallmarks of cancer. Cell 100(1): 57-70, 2000. PMID: 10647931. DOI: 10.1016/s00928674(00)81683-9

25 Hanahan D and Weinberg RA: Hallmarks of cancer: the next generation. Cell 144(5): 646-674, 2011. PMID: 21376230. DOI: 10.1016/j.cell.2011.02.013

$26 \mathrm{Li} \mathrm{L}$, Fan P, Chou H, Li J, Wang K and Li H: Herbacetin suppressed MMP9 mediated angiogenesis of malignant melanoma through blocking EGFR-ERK/AKT signaling 
pathway. Biochimie 162: 198-207, 2019. PMID: 31075281. DOI: 10.1016/j.biochi.2019.05.003

27 Treskova I, Topolcan O, Windrichova J, Simanek V, Slouka D, Treska V and Kucera R: OPG, OPN, EGF and VEGF levels at individual Breslow score stages in malignant melanoma. Anticancer Res 38(8): 4907-4911, 2018. PMID: 30061268. DOI: 10.21873/anticanres.12806

28 Bracher A, Cardona AS, Tauber S, Fink AM, Steiner A, Pehamberger H, Niederleithner H, Petzelbauer P, Gröger M and Loewe R: Epidermal growth factor facilitates melanoma lymph node metastasis by influencing tumor lymphangiogenesis. J Invest Dermatol 133(1): 230-238, 2013. PMID: 22951723. DOI: $10.1038 / \mathrm{jid} .2012 .272$

29 Foks M, Wągrowska-Danilewicz M, Danilewicz M, Bonczysta M, Olborski B and Stasikowska-Kanicka O: The number of CD163 positive macrophages is associatedwith more advanced skin melanomas, microvessels density and patient prognosis. Pol J Pathol 70(3): 217-222, 2019. PMID: 31820866. DOI: 10.5114/ pjp.2019.90399

30 Licarete E, Rauca VF, Luput L, Patras L, Sesarman A and Banciu M: The prednisolone phosphate induced suppression of the angiogenic function of tumor associated macrophages enhances the antitumor effects of doxorubicin on B16.F10 murine melanoma cells in vitro. Oncol Rep 42(6): 2694-2705, 2019. PMID: 31578578 . DOI: 10.3892/or.2019.7346

31 Mimeault M, Johansson SL and Batra SK: Pathobiological implications of the expression of EGFR, pAkt, NF-kB and MIC1 in prostate cancer stem cells and their progenies. PLoS One 7(2): e31919, 2012. PMID: 22384099. DOI: 10.1371/journal. pone.0031919

32 Pei J, Lou Y, Zhong R and Han B: MMP9 activation triggered by epidermal growth factor induced FoxO1 nuclear exclusion in non-small cell lung cancer. Tumour Biol 35(7): 6673-6678, 2014. PMID: 24705809. DOI: 10.1007/s13277-014-1850-z

33 Lutgendorf SK, Lamkin DM, Jennings NB, Arevalo JM, Penedo F, DeGeest K, Langley RR, Lucci JA 3rd, Cole SW, Lubaroff DM and Sood AK: Biobehavioral influences on matrix metalloproteinase expression in ovarian carcinoma. Clin Cancer Res 14(21): 6839-6846, 2008. PMID: 18980978. DOI: 10.1158/ 1078-0432.CCR-08-0230

34 Westekemper H, Karimi S, Süsskind D, Anastassiou G, Freistühler M, Meller D, Zeschnigk M, Steuhl KP, Bornfeld N, Schmid KW and Grabellus F: Expression of MCSP and PRAME in conjunctival melanoma. Br J Ophthalmol 94(10): 1322-1327, 2010. PMID: 20805128. DOI: 10.1136/bjo.2009.167445

35 Remmele W and Stegner HE: [Recommendation for uniform definition of an immunoreactive score (IRS) for immunohistochemical estrogen receptor detection (ER-ICA) in breast cancer tissue]. Pathologe 8(3): 138-140, 1987. PMID: 3303008.

36 Meng F, Wu L, Dong L, Mitchell AV, James Block C, Liu J, Zhang H, Lu Q, Song WM, Zhang B, Chen W, Hu J, Wang J, Yang Q, Hüttemann $\mathrm{M}$ and Wu G: EGFL9 promotes breast cancer metastasis by inducing cMET activation and metabolic reprogramming. Nat Commun 10(1): 5033, 2019. PMID: 31695034. DOI: 10.1038/s41467-019-13034-3

37 Xu Y, Xu H, Li M, Wu H, Guo Y, Chen J, Shan J, Chen X, Shen J, Ma Q, Liu J, Wang M, Zhao W, Hong J, Qi Y, Yao C, Zhang Q, Yang Z, Qian C and Li J: KIAA1199 promotes sorafenib tolerance and the metastasis of hepatocellular carcinoma by activating the EGF/EGFR-dependent epithelial-mesenchymal transition program. Cancer Lett 454: 78-89, 2019. PMID: 30980868. DOI: 10.1016/j.canlet.2019.03.049

38 Cheng JC, Auersperg N and Leung PC: EGF-induced EMT and invasiveness in serous borderline ovarian tumor cells: a possible step in the transition to low-grade serous carcinoma cells? PLoS One 7(3): e34071, 2012. PMID: 22479527. DOI: 10.1371/ journal.pone.0034071

39 Ma D and Niederkorn JY: Role of epidermal growth factor receptor in the metastasis of intraocular melanomas. Invest Ophthalmol Vis Sci 39(7): 1067-1075, 1998. PMID: 9620065.

40 Singh B, Carpenter G and Coffey RJ: EGF receptor ligands: recent advances. F1000Res 5: F1000 Faculty Rev-2270, 2016. PMID: 27635238. DOI: 10.12688/f1000research.9025.1

41 Harris RC, Chung E and Coffey RJ: EGF receptor ligands. Exp Cell Res 284(1): 2-13, 2003. PMID: 12648462. DOI: 10.1016/ s0014-4827(02)00105-2

42 Girotti MR, Pedersen M, Sanchez-Laorden B, Viros A, Turajlic S, Niculescu-Duvaz D, Zambon A, Sinclair J, Hayes A, Gore M, Lorigan P, Springer C, Larkin J, Jorgensen C and Marais R: Inhibiting EGF receptor or SRC family kinase signaling overcomes BRAF inhibitor resistance in melanoma. Cancer Discov 3(2): 158-167, 2013. PMID: 23242808. DOI: 10.1158/ 2159-8290.CD-12-0386

43 Gross A, Niemetz-Rahn A, Nonnenmacher A, Tucholski J, Keilholz $U$ and Fusi A: Expression and activity of EGFR in human cutaneous melanoma cell lines and influence of vemurafenib on the EGFR pathway. Target Oncol 10(1): 77-84, 2015. PMID: 24824730. DOI: 10.1007/s11523-014-0318-9

44 Mao M, Tian F, Mariadason JM, Tsao CC, Lemos R Jr, Dayyani F, Gopal YN, Jiang ZQ, Wistuba II, Tang XM, Bornman WG, Bollag G, Mills GB, Powis G, Desai J, Gallick GE, Davies MA and Kopetz S: Resistance to BRAF inhibition in BRAF-mutant colon cancer can be overcome with PI3K inhibition or demethylating agents. Clin Cancer Res 19(3): 657-667, 2013. PMID: 23251002. DOI: 10.1158/1078-0432.CCR-11-1446

45 Ng YK, Lee JY, Supko KM, Khan A, Torres SM, Berwick M, Ho J, Kirkwood JM, Siegfried JM and Stabile LP: Pan-erbB inhibition potentiates BRAF inhibitors for melanoma treatment. Melanoma Res 24(3): 207-218, 2014. PMID: 24709886. DOI: 10.1097/CMR.0000000000000060

46 Zalesna I, Osrodek M, Hartman ML, Rozanski M, SztillerSikorska M, Niewinna K, Nejc D and Czyz M: Exogenous growth factors bFGF, EGF and HGF do not influence viability and phenotype of V600EBRAF melanoma cells and their response to vemurafenib and trametinib in vitro. PLoS One 12(8): e0183498, 2017. PMID: 28829835. DOI: 10.1371/ journal.pone. 0183498

47 Jensen TO, Schmidt H, Møller HJ, Høyer M, Maniecki MB, Sjoegren P, Christensen IJ and Steiniche T: Macrophage markers in serum and tumor have prognostic impact in American Joint Committee on Cancer stage I/II melanoma. J Clin Oncol 27(20): 3330-3337, 2009. PMID: 19528371. DOI: 10.1200/JCO. 2008.19.9919

48 Jakobiec FA, Folberg R and Iwamoto T: Clinicopathologic characteristics of premalignant and malignant melanocytic lesions of the conjunctiva. Ophthalmology 96(2): 147-166, 1989. PMID: 2649838. DOI: 10.1016/s0161-6420(89)32920-4

49 Storr SJ, Safuan S, Mitra A, Elliott F, Walker C, Vasko MJ, Ho B, Cook M, Mohammed RA, Patel PM, Ellis IO, Newton- 
Bishop JA and Martin SG: Objective assessment of blood and lymphatic vessel invasion and association with macrophage infiltration in cutaneous melanoma. Mod Pathol 25(4): 493-504, 2012. PMID: 22080065. DOI: 10.1038/modpathol.2011.182

50 Gao L, Wang FQ, Li HM, Yang JG, Ren JG, He KF, Liu B, Zhang $\mathrm{W}$ and Zhao YF: CCL2/EGF positive feedback loop between cancer cells and macrophages promotes cell migration and invasion in head and neck squamous cell carcinoma. Oncotarget 7(52): 87037-87051, 2016. PMID: 27888616. DOI: 10.18632/oncotarget.13523

51 Nabeshima A, Matsumoto Y, Fukushi J, Iura K, Matsunobu T, Endo M, Fujiwara T, Iida K, Fujiwara Y, Hatano M, Yokoyama N, Fukushima S, Oda Y and Iwamoto Y: Tumour-associated macrophages correlate with poor prognosis in myxoid liposarcoma and promote cell motility and invasion via the HBEGF-EGFR-PI3K/Akt pathways. Br J Cancer 112(3): 547-555, 2015. PMID: 25562433. DOI: 10.1038/bjc.2014.637

52 Rigo A, Gottardi M, Zamò A, Mauri P, Bonifacio M, Krampera M, Damiani E, Pizzolo G and Vinante F: Macrophages may promote cancer growth via a GM-CSF/HB-EGF paracrine loop that is enhanced by CXCL12. Mol Cancer 9: 273, 2010. PMID: 20946648. DOI: $10.1186 / 1476-4598-9-273$

53 Lin EY, Gouon-Evans V, Nguyen AV and Pollard JW: The macrophage growth factor CSF-1 in mammary gland development and tumor progression. J Mammary Gland Biol Neoplasia 7(2): 147-162, 2002. PMID: 12465600 . DOI: 10.1023/ a: 1020399802795

54 Pollard JW: Macrophages define the invasive microenvironment in breast cancer. J Leukoc Biol 84(3): 623-630, 2008. PMID: 18467655. DOI: $10.1189 /$ jlb.1107762

55 Kim HK, Chae SW, Woo KI and Kim YD: Expression of matrix metalloproteinase (MMP)-2, MMP-9, and tissue inhibitor of MMP (TIMP)-1 in conjunctival melanomas and clinical implications. Jpn J Ophthalmol 54(3): 221-226, 2010. PMID: 20577856. DOI: 10.1007/s10384-009-0793-1
56 Candrea E, Senila S, Tatomir C and Cosgarea R: Active and inactive forms of matrix metalloproteinases 2 and 9 in cutaneous melanoma. Int J Dermatol 53(5): 575-580, 2014. PMID: 23036130. DOI: 10.1111/j.1365-4632.2012.05772.x

57 van den Oord JJ, Paemen L, Opdenakker G and de Wolf-Peeters $\mathrm{C}$ : Expression of gelatinase $\mathrm{B}$ and the extracellular matrix metalloproteinase inducer EMMPRIN in benign and malignant pigment cell lesions of the skin. Am J Pathol 151(3): 665-670, 1997. PMID: 9284814.

58 Liu L, Ye Y and Zhu X: MMP-9 secreted by tumor associated macrophages promoted gastric cancer metastasis through a PI3K/AKT/Snail pathway. Biomed Pharmacother 117: 109096, 2019. PMID: 31202170. DOI: 10.1016/j.biopha.2019.109096

59 Zhang XM, Wang T, Hu P, Li B, Liu H and Cheng YF: SERPINB2 overexpression inhibited cell proliferation, invasion and migration, led to $\mathrm{G} 2 / \mathrm{M}$ arrest, and increased radiosensitivity in nasopharyngeal carcinoma cells. J Radiat Res 60(3): 318-327, 2019. PMID: 30864656. DOI: 10.1093/jrr/rrz003

60 Al-Salam S, Hameed R, Parvez H and Adeghate E: Pattern of distribution of IGF-1 and EGF in pancreatic islets of type 2 diabetic patients. Islets 1(2): 102-105, 2009. PMID: 21099256. DOI: $10.4161 /$ isl.1.2.9273

Received June 25, 2021

Revised July 30, 2021

Accepted August 4, 2021 